\section{Back to Basics: Clinical versus Radiologic Recognition of Spondyloarthropathy}

\section{To the Editor:}

The report by Christiansen, $e a^{1}$ again emphasizes one of the limitations to clinical application of our diagnostic paradigms. Sacroiliac joints (SIJ) have highly irregular contours with 3-D topography ${ }^{2}$. Imaging artifacts related to the limited resolution of computed tomography (related to the subchondral bone thickness of SIJ) compromises its reliability in identifying or excluding not only erosions, but also bridging or fusion ${ }^{3,4}$. Standard radiographs also have limited resolution, but no averaging artifact. One would anticipate that they would provide clarity, and they generally do for most joints. SIJ are an exception ${ }^{1,3}$. The irregular characteristic of the joint and its positioning outside of visualization on standard anterior-posterior and lateral views are thought responsible for erroneous perspectives of the "health" of the joint ${ }^{5}$. However, experimentation with alternative views (Table 1) failed to provide a solution ${ }^{3}$.

The category of disease inclusive of ankylosing spondylitis (AS) and spondyloarthropathy (SpA) in general is a construct. Clinical, laboratory, and radiologic findings have been used to facilitate its recognition. However, it is perhaps useful to examine the clinical purpose of categorization. Is it not to define a clinical population that would be anticipated to respond to a specific course of treatment?

Back pain that is worse with immobility, improved with activity, and associated with significant morning stiffness is highly characteristic, although arguably not definitive for the diagnosis of AS or at least the axial presentation of $\mathrm{SpA}^{6}$. If radiologic findings are not always reliable ${ }^{1,3}$, the value of HLA-B27 positivity is limited by its high presence in healthy

Table 1. Radiologic views for sacroiliac joint visualization ${ }^{3}$.

$$
\begin{gathered}
\text { Anterior-posterior (AP) } \\
30^{\circ} \text { cephalad-angulated AP } \\
15^{\circ} \text { cephalad-angulated AP } \\
30^{\circ} \text { caudally angulated posterior-anterior } \\
\text { Obliques } \\
\text { Stereoscopic } \\
\text { Tomograms } \\
\text { CT scans } \\
\text { Fluoroscopy }
\end{gathered}
$$

individuals ${ }^{7}$, and acute-phase reactants are variable ${ }^{8}$, is therapeutic response an alternative diagnostic consideration? If the patient's pain complaints respond to an extension exercise program (with avoidance of flexion activities), the diagnosis of SpA is highly likely ${ }^{9}$. After all, we are clinicians and from a clinical perspective, the patient's problem has been resolved.

BRUCE ROTHSCHILD, MD, Professor of Medicine, West Virginia University, and Research Associate, Carnegie Museum, Morgantown, West Virginia, USA. Address correspondence to Dr. B. Rothschild, Department of Medicine, West Virginia University School of Medicine, Morgantown, West Virginia 26506, USA. E-mail: spondylair@gmail.com

\section{REFERENCES}

1. Christiansen AA, Hendricks O, Kuettel D, Hørslev-Petersen K, Jurik AG, Nielsen S, et al. Limited reliability of radiographic assessment of sacroiliac joints in patients with suspected early spondyloarthritis. J Rheumatol 2017;44:70-7.

2. Solonen KA. The sacroiliac joint in the light of anatomical, roentgenological and clinical studies. Acta Orthop Scand Suppl 1957;27:1-127.

3. Rothschild BM, Poteat GB, Williams E, Crawford WL. Inflammatory sacroiliac joint pathology: evaluation of radiologic assessment techniques. Clin Exp Rheum 1994;12:267-74.

4. Lawson TL, Foley WD, Carrera GF, Berland LL. The sacroiliac joints: anatomic, plain roentgenographic, and computed tomographic analysis. J Comput Assist Tomogr 1982;6:307-14.

5. Yazici H, Turunç M, Ozdoğan H, Yurdakul S, Akinci A, Barnes CG. Observer variation in grading sacroiliac radiographs might be a cause of 'sacroiliitis' reported in certain disease states. Ann Rheum Dis 1987;46:139-45.

6. Inman R, Sieper J. Oxford textbook of axial spondyloarthritis. Oxford: Oxford University Press; 2016.

7. Sheehan NJ. The ramifications of HLA-B27. J R Soc Med 2004;97:10-14

8. Laurent MR, Panayi GS. Acute-phase proteins and serum immunoglobulins in ankylosing spondylitis. Ann Rheum Dis 1983;42:524-8.

9. Rothschild B. Mechanical/enthesial origin for ankylosing spondylitis axial involvement? Clues from a therapeutic viewpoint. J Arthritis 2014;3:120

J Rheumatol 2017;44:6; doi:10.3899/jrheum.170164

CT: computed tomography. 